Mexican extraction. It was in this period that there was an outburst of architectural activity, in which the fundamental conception was Mayan, but the presence of an alion influence is to be soen in serpent columns, sloping lower walls, and othor features.

The Temple of the Wall Panels was chosen for excavation on account of its central position in what is known as the Monjas group. This group would appear to have been the nucleus of the city, as it contains most of the pure Mayan buildings of Chichen Itzá, as well as structures that are doubtful and others that are certainly Nahua. The Temple of the Wall Panels was seen to bo late from the presence of the drums of round columns on the mound; but beyond the fact that it was small, before excavation nothing was to bo seen of its original plan or elevation. When finally cleared, it was found to face west and to consist of a solid pyramidal substructure surmounted by a temple, with a colonnade, forming an integral part of the building, lying directly to the west. 'The entire edifice rests on a terrace reached by two steps. The temple consisted of two chambers, each covered by a vaulted roof. Of the outer facing, little remains. In the debris of the talus on the northern and southern sides were discovered scuiptured stones from panels and mask elements which had fallen from the outer walls. Two warriors are represented on the north panel, one having a long-noso head and an elaborate feathered headdress. The figures are the full height of the panels.

The entrance to the outer chamber is by a triple doorway, 6.71 metres wide, divided by two round columns. Hach chamber has a crudo shrine or altar. In the inner room a beautifully carved stone was discovered, the figures representing warriors.

In excavating the colonnade, of which the roof probably formed the approach to the temple, sculp. tured stones were found which had fallen face down.
They were for the most part in sequence and have been fitted together. They proved to be elements of the pancls of the exterior walls. They were not executed with that fineness of which the Chichen Itzá artists were capable, and it is evident that for detail and finish dependence was placed on the stuceo, of which some still adheres to the stone. These panels are elaborately earved with numerous figures of men and animals.

Certain features justify the assignment of the temple to the Nahua period. These are the colonnade, serpent columns, roof adornos, a battered basal zone, sculptured panels depicting feathered serpents, the acoutre. ments of the warriors, and the sun-disk motive. The Atlantean figures which form part of the Nahua sculptural complex are here represented only in a column drum which had been re-used. This presupposes the building and razing of a structure of Nahua type before the erection of the Temple of the Wall Panels.

(4) The metate or milling stone upon which the pcoples of aboriginal America grind their maize-corn was, and still is, among many of the Indian tribes the most important article of household equipment. Exeept for certain ceremonial examples from Central America, it is normally of simple and purely utilitarian form. This typological stability gives it a peculiar archæological significance, as it is littlo likely to be affected by fortuitous circumstance. It is therefore an admirable source of evidence for certain fundamental groupings. The metutes of Chichen Itzá are considered by Dr. Strúmsvik as falling into a classification of 'heavy grooved type', 'three-legged ungrooved large type', and 'three-legged ungrooved small type'. While suggesting the intrusion of an alien influence, he points to the necessity of more data on the distribution and cultural affinitics of grooved and ungrooved metates in Mexico and Contral America.

\title{
The A.I.V. Process of Conserving Green Fodder
}

TN these days of economic nationalism and of devalued currency in terrns of gold, it is a cardinal principle to produce as much at home as natural conditions allow. Although only the Dr. Panglosses believe that Great Britain could foed her people entirely and adequately from her own resources, yet all who have studied the question think that we could go a long way towards this goal. Great Britain, for example, is one of the most favoured nations in regard to grass production, yet it imports many million pounds' worth each of butter, cheese, eggs, meat, and concentrated feeding stuffs which could be produced at home. The annual bill for imported concentrated foods is so high that efforts have been made recently to dry artificially the young, protein-rich grass and so conserve it for winter 'keep'. Up to date, experiments made with this object in view in Germany and Great Britain have failed to bring conviction to the economist, and it now looks as if the desired end is to be achieved by a modification of the old practice of ensiling. The ensiling of green fodder crops for use as winter keep has made great headway in New Zealand, the United States, Holland, and Germany, but the English farmer has been slow to realise its advantages. However, he has now an opportunity. Thanks to the enterprise of Imperial Chemical Industries, Ltd., a new chemical method of ensiling, which hails from Finland, has been launched in Great Britain, large-scale experiments having been undertaken at the company's research station at Jealott's Hill, Berks, and at various other places.
When ensilage is made in the ordinary way, in tower, stack, or pit, the greon fodder undergoes various changes, due to enzymes and bacteria, which usually entail a loss of 15-30 per cent of its nutrients, and much more if anything goes wrong with the process, In the new Finnish process-called the A.I.V. process, after the initials of the discoverer, Prof. A. I. Virtunen - such changes are inhibited by maintaining the fodder at a hydrogen ion concentration of 3-4. This is achieved by spraying a dilute acid liquor on to the green crop as it is charged into a pit silo; and mould. growth is prevented by spraying the top layer with an anti-mould preparation, called 'Homesurma' (mould-death). 'The composition of the acid liquor is not revealed, but it is stated to consist mainly of hydrochloric acid, whilst 'Homesurma' is said to consist chiefly of allyl mustard oil. When the pit is fully charged, it must be sealed on the top as tightly as possible, for example, by means of sacking covered with clay or loam, as ingress of air is fatal to success. According to Prof. Virtanen, A.I.V. fodder contains a much higher content of digestible protein than ordinary silage; and he estimates the loss of nutrients in the preparation to be 0.2 per cent from respiration, nothing from decomposition of proteins, and 1.3 per cent from escaped juice.

The A.I.V. process has achieved remarkable success in Finland, where it has been taken up by the butter co-operative export society, Valio, which controls 90 per cent of the butter exported from that country, In 1927 and 1928 , the process was being worked out 
and tested mainly in the laboratory; in 1929, it was used on 3000 farms, and 30,000 metric tons of A.I.V. fodder was produced; in 1931, 100,000 tons was made on approximately 10,000 farms; and in 1932 the process is being used on 13,000 farms. All kinds of green crops have been ensiled, but legumes or young grass are best for feeding to milch cows.

The ordinary winter ration used in Finland for 800 -gallon cows consists of concentrates, turnips, hay and straw : in the A.I.V. ration, all the turnips and much (in some cases all) of the concentrates are eliminated, together with much of the hay. Expenditure on imported concentrates has been reduced by 50-80 per cent, and at the same time the milk yield has increased. The animals readily eat the fodder, ensiled grass being preferred. The free acid is said to disappear before the fodder is fed, but on most of the Finnish farms using the process a small amount of chalk is included in the silage ration. It has been found that the animals do not tire of A.I.V. fodder, and that their general health remains excellent: the distribution of lime and phosphorus in the teeth and bones, and of lime, phosphorus, and chlorine in the muscles and blood, remains normal. The quality of the milk resembles that of summer milk, both the butter-fat and protein contents being slightly higher than when the cows are fed on the ordinary winter ration; and the butter made from winter milk lacks its usual brittleness owing to the oleic acid-content being maintained at summer level. Further, the high vitamin content is held to be of great importance to public health, as the majority of the inhabitants of northern countries rely mainly on milk and milk products for their supplies of vitamins $A$ and D, and hitherto it has been found that the growth of children in Finland is practically confined to the months from July to December.
The only capital cost involved is that of making the silo pit, which has a diameter of $16 \frac{1}{2} \mathrm{ft}$. and a depth of $4 \mathrm{ft}$. 9 in. In Finland, where family labour is abundant and wood is cheap, this cost is very low. Unless the subsoil is chalk, the pit must be lined with wood, or with cement if there is danger of water seepage. A light wooden superstructure, which is transferable from pit to pit, must also be provided; it is placed over the pit when the green material reaches the ground level, and filling then proceeds until the superstructure is also full. The fresh material is then weighted, in a day or two it sinks to the ground level, and the superstructure is removed. Working costs vary with the crop ensiled, the yield per acre of the crop, and with the cost and efficiency of the labour. With labour, as in England, at about $8 d$. per hour, the cost per ton of dry matter (about twenty per cent of the green weight) is estimated to be about $22 s .6 d$. ; if to this figure we add $£ 2$ per ton of dry matter as the inclusive cost of growing grass for ensilage with the aid of manures, we obtain a total of $£ 32 s .6 d$. per ton, to which must be added a further small sum for cost of acid and depreciation of the silage pit.

Large-scale trials of the process are being made in Denmark as well as in Great Britain; in addition, the process has found a footing in Sweden and Norway; whilst in Germany, where some of Prof. Virtanen's claims are contested, the process, in its essential principles, has been officially adopted and is being widely advocated. If found to be a success in Great Britain, the adoption of the process will not only save the country millions of pounds per annum on imported concentrates, but will also provide what appears to be the only practical, economic solution of the problem of utilising flush growth of grass, which is one of outstanding importance in the management of grassland.

\section{Buffalo-Fly in Northern Australia}

HOR years past, serious complaints have come from cattle raisers in the northern areas of Australia about heavy economic losses due to irritation of stock by the buffalo-fly. This led the Commonwealth Council for Scientific and Industrial Research in 1930 to invite Prof. Eduard Handschin, of Basle, to undertake inquiries in Java and neighbouring islands, as well as on the mainland. The object was to examine possibilities of parasitic control of the pest. Prof. Handschin's full report is not yet available, but it is of interest at this stage to record some of the results of his eighteen months' work.

As with other alleged economic pests in Australia (flying fox, for example), careful inquiry has shown that Lyperosia exigua de Meijere, though serious in some places, is by no means responsible for all the damage hitherto attributed to it. This fly is present everywhere in the Dutch East Indies, where it is not regarded as a pest : its bad name in Australia is due in part to faulty observation. March and bush flies (Tabanus and Biomyia spp.) worry cattle more, in Handschin's opinion, than does Lyperosia. Loss of condition in travelling mobs is often put down to 'fly worry' when it is due rather to innutritious dry grass and water scarcity. Further, the quality of the stock in northem Australia is admittedly low. This undoubtedly increases the attractiveness, or susceptibility, of the cattle to the fly. Poor quality of stock is probably a cause rather than an effect of the abnormally heavy infestation that is frequently observed. In short, it is usual to attribute all fly damage to Lyperosia and to make it the scapegoat for every economic loss in northern Australia.
Nevertheless, it remains a distinct menace to cattleraising, and its passage eastwards into the dairying herds of the coastal areas of Queensland might have serious results. Such spread is already occurring, but its geographic limits are set by conditions of temperature and humidity. The influence of these on time of development has been partially worked out by Handschin, who feels justified in maintaining that the buffalo-fly will never become established in the more southerly parts of Australia (western or eastern) and probably never farther south than Rockhampton in Queensland. There may be temporary incursions to lower latitudes, but they will not survive.

In the sparsely settled areas of the north, parasitism seems the only possible means of control. Nieschulz had already found a number of parasites in Java, mostly primary parasites of saprophagous Muscidoe, not confined to any species of these, but as easily bred on Lyperosia as on them. Twelve of them were reared in the laboratories of the Veterinary Research Institute at Buitenzorg, and Spalangia sundaica Graham (n. sp.), which was the must abundant in the field, offered the greatest promise as a possible control for Lyperosia. The female lives about 27 days and lays 160-170 eggs, each in a separate puparium of a fly.

There is a northem Australian species tentatively named $S$. orientalis Graham (n. sp.), morphologically quite distinct from $S$. sundaica, the female of which lives for 15 days and lays 75-85 eggs. In the hope of producing a more effective race, Handschin endeavoured to cross these two species. Males only were produced, indicating that fertilisation had not occurred. In the meantime, however, a special strain

No. 3290, Vol. 130] 